Article

\title{
Preparation and Characterization of Iron-Doped Tricalcium Silicate-Based Bone Cement as a Bone Repair Material
}

\author{
Yanan Zhang ${ }^{1}$, Jiapan Luan ${ }^{1}$, Yin Zhang ${ }^{1,2, *}$, Shuai Sha ${ }^{1}$, Sha $\mathrm{Li}^{1}$, Shanqi $\mathrm{Xu}^{1}$ and \\ Dongqing $\mathrm{Xu}{ }^{1}$ \\ 1 College of Materials Science and Engineering, Nanjing Tech University, Nanjing 211816, China; \\ zyn3648@njtech.edu.cn (Y.Z.); 201861103064@njtech.edu.cn (J.L.); 201961203152@njtech.edu.cn (S.S.); \\ 201961103082@njtech.edu.cn (S.L.); 201961103075@njtech.edu.cn (S.X.); 4201170305@njtech.edu.cn (D.X.) \\ 2 Nanjing Haoqi Advanced Materials Co., Ltd., Nanjing 211300, China \\ * Correspondence: zhang.512@njtech.edu.cn
}

Received: 11 July 2020; Accepted: 17 August 2020; Published: 19 August 2020

\begin{abstract}
Iron is one of the trace elements required by human body, and its deficiency can lead to abnormal bone metabolism. In this study, the effect of iron ions on the properties of tricalcium silicate bone cement $\left(\mathrm{Fe} / \mathrm{C}_{3} \mathrm{Ss}\right)$ was investigated. It effectively solved the problems of high $\mathrm{pH}$ value and low biological activity of calcium silicate bone cement. The mechanical properties, in vitro mineralization ability and biocompatibility of the materials were systematically characterized. The results indicate that tricalcium silicate bone cement containing $5 \mathrm{~mol} \%$ iron displayed good self-setting ability, mechanical properties and biodegradation performance in vitro. Compared with pure calcium silicate bone cement $\left(\mathrm{C}_{3} \mathrm{Ss}\right), \mathrm{Fe} / \mathrm{C}_{3} \mathrm{Ss}$ showed lower $\mathrm{pH}$ value (8.80) and higher porosity (45\%), which was suitable for subsequent cell growth. Immersion test in vitro also confirmed its good ability to induce hydroxyapatite formation. Furthermore, cell culture experiments performed with $\mathrm{Fe} / \mathrm{C}_{3} \mathrm{Ss}$ ion extracts clearly stated that the material had excellent cell proliferation abilities compared to $\mathrm{C}_{3} \mathrm{Ss}$ and low toxicity. The findings reveal that iron-doped tricalcium silicate bone cement is a promising bioactive material in bone repair applications.
\end{abstract}

Keywords: bone cement; tricalcium silicate; Fe-doped; biocompatibility

\section{Introduction}

Bone tissue defects and injuries are common diseases in clinic. Bone defect sites, usually caused by aging, trauma and other reasons, do not have the ability to complete self-repair, which usually seriously affects people's normal life [1,2]. De Grado et al. and Winkler et al. reviewed the existing shortcomings, clinical applications and future prospects of various bone repair materials for treating bone defects $[3,4]$. At present, among many methods to treat bone defects, traditional bone repair techniques are still used in clinic, such as autogenous bone, allogeneic bone, metal materials, etc. [5]. In addition to autogenous bone with limited bone mass, other biomaterials do not yet possess good biocompatibility, degradability and porous three-dimensional structure. Due to the inherent shortcomings of these materials, traditional bone repair techniques are limited in curing bone defect diseases [6].

To overcome the deficiency of traditional bone repair materials, modern bone repair materials have been rapidly developed, and bone cement is one of them. Some studied have found that bone cement biomaterials, such as calcium phosphate, calcium silicate and calcium sulfate, have good biocompatibility, self-setting behavior and can be shaped arbitrarily [7-9]. For example, Ho et al. found calcium silicate bone cement had good bioactivity and osteogenic ability, and it could be used as bone defect repair material [10]. Bone cements have excellent prospects for bone repair, but there are also 
many deficiencies, such as limited mechanical strength and biological activity. At the same time, better degradation rates, suitable setting time and porosity and mineralization capabilities are also problems that need to be further studied and solved in bone cement materials [11-13]. In addition, enhancing the osteogenic ability of bone cement materials to accelerate bone healing can improve the repair effect of bone defects, which is of great significance in clinic.

Among bone cement biomaterials, calcium silicate-based materials have received extensive attention due to their excellent osteogenicity, biodegradability and mechanical strength [14-17]. Calcium silicate can also degrade in vivo and release silicon element for promoting human bone growth [18]. Tricalcium silicate $\left(C_{3} S\right)$ is a typical calcium silicate-based biomaterial, which has a major role in the field of orthopedics due to its self-setting property, biological activity and the ability to fill irregular shape defects [19]. Although $C_{3} S$ has many advantages, the biological activity is still low and needs to be further improved. At the same time, the hydration of $\mathrm{C}_{3} \mathrm{~S}$ generates the highly basic byproduct calcium hydroxide $\left(\mathrm{Ca}(\mathrm{OH})_{2}\right)$, which is rapidly ionized and modified to generate Ca ions and $\mathrm{OH}^{-}$[20]. Ca ion can promote osteogenic differentiation and mineralization of bone cells [21,22], while free $\mathrm{OH}^{-}$may increase $\mathrm{pH}$ value and result in inflammation [19]. Iron, an important basic element in bone tissue, plays a key role in bone growth and metabolism [23]. The formation of $\mathrm{Ca}(\mathrm{OH})_{2}$ can be reduced by incorporating $\mathrm{Fe}^{3+}$ into the $\mathrm{C}_{3} \mathrm{~S}$ compound to replace a part of $\mathrm{Ca}^{2+}$. Furthermore, the ion release and metabolism of iron-containing biomaterials have also attracted researchers' attention [24]. Zhang et al. reported that mouse bone marrow stromal cells cultured on Fe-doped tricalcium phosphate had good adhesion morphology and proliferation capacity, and the expression of osteogenesis-related genes was significantly enhanced [25]. Xia et al. also confirmed that the introduction of iron into calcium phosphate cement scaffolds can enhance bone regeneration [26]. Therefore, introducing iron into bone cement may be beneficial to improve the cell proliferation capability.

In this study, a new type of iron-containing biological bone cement was prepared; the influences of different concentrations on $\mathrm{C}_{3} \mathrm{~S}$ bone cement properties, such as setting time, compressive strength, porosity and anti-washout property were investigated; and in vitro experiments were systematically performed. An in vitro immersion study was conducted in simulated body fluids (SBF). The mineralization ability of Fe-doped tricalcium silicate bone cement $\left(\mathrm{Fe} / \mathrm{C}_{3} \mathrm{~S}\right)$ biomaterials was evaluated by XRD, FT-IR and SEM. Moreover, mouse fibroblasts (L929 cells) were utilized to evaluate the cell proliferation ability and cytotoxicity of $\mathrm{Fe} / \mathrm{C}_{3} \mathrm{Ss}$ bone cement materials.

\section{Materials and Methods}

\subsection{Preparation of Pure $C_{3} S$ and Fe-Doped $C_{3} S$ Powders}

$\mathrm{C}_{3} \mathrm{~S}$ and Fe-doped tricalcium silicate $\left(\mathrm{Fe} / \mathrm{C}_{3} \mathrm{~S}\right)$ powders were synthesized by sol-gel method [27]. Briefly, 2-M nitric acid solution $\left(\mathrm{HNO}_{3}\right.$, as a catalyst), absolute ethanol $\left(\mathrm{C}_{2} \mathrm{H}_{5} \mathrm{OH}\right.$, as a solvent), calcium nitrate tetrahydrate $\left(\mathrm{Ca}\left(\mathrm{NO}_{3}\right)_{2} \cdot 4 \mathrm{H}_{2} \mathrm{O}\right.$, XiLong Chemical Co., Ltd., Shantou, China) and ferric nitrate nonahydrate $\left(\mathrm{Fe}\left(\mathrm{NO}_{3}\right)_{3} \cdot 9 \mathrm{H}_{2} \mathrm{O}\right.$, Saan Chemical Technology Co., Ltd., Shanghai, China) were sequentially added to tetraethyl orthosilicate (TEOS, Sinopharm group Co., Ltd., Shanghai, China). Then, it was stirred well for $1 \mathrm{~h}$. The molar ratio of TEOS- $\mathrm{HNO}_{3}-\mathrm{C}_{2} \mathrm{H}_{5} \mathrm{OH}$ was 10:10:1. The iron ion accounted for 0 , $2.5,5$ and $10 \mathrm{~mol} \%$ of the total metal cation concentration, respectively. Then, the above mixed solution was aged at $60^{\circ} \mathrm{C}$ for $48 \mathrm{~h}$, followed by drying for $48 \mathrm{~h}$ at $120^{\circ} \mathrm{C}$. Next, the gel was heated to $1450{ }^{\circ} \mathrm{C}$ at a rate of $5{ }^{\circ} \mathrm{C} / \mathrm{min}$, and then kept in a high temperature resistance furnace for $8 \mathrm{~h}$. Finally, the sintered powder was finely ground in an agate mortar and sieved with a 300 mesh for further studies.

\subsection{Preparation of Bone Cement}

The $\mathrm{C}_{3} \mathrm{~S}$ or $\mathrm{Fe} / \mathrm{C}_{3} \mathrm{~S}$ powder was mixed with $0.5-\mathrm{M}$ dipotassium hydrogen phosphate solution, which served as curing liquid. The liquid to powder ratio was $0.3 \mathrm{~mL} / \mathrm{g}$. When stirred into paste, the solution was promptly filled into the mold ( $\Phi 6 \mathrm{~mm} \times 3 \mathrm{~mm}$ or $\Phi 6 \mathrm{~mm} \times 12 \mathrm{~mm}$ ) to obtain a 
unified shape for the following experiments. The Fe/ $\mathrm{C}_{3} \mathrm{~S}$ bone cements were named as Fe-0, Fe-2.5, Fe-5 and Fe-10 according to the Fe-doped concentrations of 0, 2.5, 5 and $10 \mathrm{~mol} \%$, respectively.

\subsection{Material Properties Evaluation}

According to ASTM C266-15 [8], the final setting time of samples $(\Phi 6 \mathrm{~mm} \times 12 \mathrm{~mm}, \mathrm{n}=4)$ was measured by utilizing the Gilmore needle indentation technique. Setting time was determined by Gilmore needle ( $1 \mathrm{~mm}$ in diameter and $453 \mathrm{~g}$ in weight). The setting time was recorded from when the solid-liquid phase was uniformly mixed to when the Gilmore needle could not produce a 1-mm deep indentation on the surface of mixture.

The preparation of $\mathrm{C}_{3} \mathrm{Ss}$ and $\mathrm{Fe} / \mathrm{C}_{3}$ Ss samples $(\Phi 6 \mathrm{~mm} \times 12 \mathrm{~mm}, \mathrm{n}=4)$ were carried out by the above method. The demolded samples were placed in a curing box at $37{ }^{\circ} \mathrm{C}$ and $100 \%$ relative humidity for $72 \mathrm{~h}$. Thereafter, those samples were dried at $37^{\circ} \mathrm{C}$ for $24 \mathrm{~h}$ and polished to measure the compressive strength. The compressive strength of bone cement sample was tested through an electronic universal testing machine (TFW-2S, Tuofeng Instrument Co., Ltd., Shanghai, China), and the cross head descending rate was $0.5 \mathrm{~mm} / \mathrm{min}$.

According to ISO standard 39231/1-1979(E) [28], the porosity of $\mathrm{C}_{3}$ Ss and $\mathrm{Fe} / \mathrm{C}_{3} \mathrm{Ss}$ samples was measured by liquid displacement (Archimedes) method. Firstly, the samples $(\Phi 6 \mathrm{~mm} \times 12 \mathrm{~mm}, \mathrm{n}=4)$ were dried and then weighed to get dry weight. Secondly, the samples were suspended in deionized water to obtain suspended weight. Finally, the samples were completely immersed in deionized water and vacuum filtered to record wet weight. Equation (1) was used to calculate the porosity value of the sample.

$$
\operatorname{Porosity}(\%)=\frac{\left(M_{3}-M_{1}\right) \times \rho}{M_{3}-M_{2}} \times 100 \%
$$

where $\rho, M_{1}, M_{2}$ and $M_{3}$ are, respectively, the density of water, dry weight, suspended weight and wet weight of the samples.

\subsection{In-Vitro Immersion Study}

Experiments can be performed in human simulated body fluids (SBFs), which are used for in vitro immersion [29]. The preparation of SBF was based on a previous study [30]. The samples $\left(\Phi 6 \mathrm{~mm} \times 3 \mathrm{~mm}\right.$ ) of $\mathrm{C}_{3} \mathrm{Ss}$ and $\mathrm{Fe} / \mathrm{C}_{3} \mathrm{Ss}$ were immersed in SBF solution at $37^{\circ} \mathrm{C}$ for $1 \mathrm{~h}$. The samples' surface morphology before and after immersion were observed and compared. If there is no obvious particle collapse or dispersion, it indicates that bone cement has a good anti-washout property [31].

The $\mathrm{pH}$ values of each bone cement sample $(\Phi 6 \mathrm{~mm} \times 3 \mathrm{~mm}, \mathrm{n}=4)$ soaked in SBF solution for different times $(0,1,3,5$ and 7 days) were detected with a $\mathrm{pH}$ meter (PHSJ-3F, Yidian Instrument Co., Ltd., Shanghai, China) [32]. The liquid-solid ratio was $20 \mathrm{~mL} / \mathrm{g}$ [33].

The weight loss was used as a function of immersing time to evaluate the biodegradability of the discs $(\Phi 6 \mathrm{~mm} \times 3 \mathrm{~mm}, \mathrm{n}=4)$. The SBF solution was renewed every two days with a solution volume to disc surface area of $10 \mathrm{~mL} / \mathrm{cm}^{2}$ [34]. After discs were immersed in SBF solution for different time $\left(0,7,14,21\right.$ and 28 days), they were dried at $60{ }^{\circ} \mathrm{C}$ for $24 \mathrm{~h}$ and then weighed. According to Equation (2), the weight loss of the sample was measured.

$$
\text { Weightloss }(\%)=\frac{M_{5}-M_{4}}{M_{4}} \times 100 \%
$$

where $M_{4}$ and $M_{5}$ represent the initial weight of the disc and the dry weight of the disc after immersing different time.

\subsection{Phase Composition and Microstructure}

The phase composition of $\mathrm{C}_{3} \mathrm{~S}$ and $\mathrm{Fe} / \mathrm{C}_{3} \mathrm{~S}$ powders before and after immersion in $\mathrm{SBF}$ solution was analyzed by diffraction of X-rays (XRD, Geigerflex, Rigaku, Tokyo, Japan). Fourier transform infrared 
spectroscopy (FT-IR, NEXUS 670, Nicolet, Beijing, China) further determined the phase composition and chemical bonds of these powders. Surface morphology of discs immersed in SBF solution for 7 days was observed using scanning electron microscopy (SEM, JSM-IT300, JEOL, Tokyo, Japan).

\subsection{In Vitro Cell Culture Test}

The cell viability of L929 mouse fibroblasts (Shanghai TongWei Biotechnology Co., Ltd., Shanghai, China) was used for cell culture test to assess cell proliferation and cytotoxicity [32]. The cells were cultured in the Dulbecco's modified eagle medium (DMEM) containing 10\% fetal bovine serum and stored in incubator with $5 \% \mathrm{CO}_{2}$ and $95 \%$ relative humidity at $37{ }^{\circ} \mathrm{C}$ [35]. Before the cell culture experiment, all cement discs $(\Phi 6 \mathrm{~mm} \times 3 \mathrm{~mm})$ were sterilized at $160^{\circ} \mathrm{C}$ for $8 \mathrm{~h}$. The $\mathrm{C}_{3} \mathrm{Ss}$ and $\mathrm{Fe} / \mathrm{C}_{3} \mathrm{Ss}$ discs were immersed in DMEM for 3 days at $4{ }^{\circ} \mathrm{C}$ to prepare ion extracts, and the solid to liquid ratio was $0.2 \mathrm{~g} / \mathrm{mL}$ [36]. The cultured cells were planted in the extract for 24,48 and $72 \mathrm{~h}$, respectively, to evaluate the cell proliferation abilities and toxicity tests of the materials.

\subsubsection{Cell Proliferation}

The proliferation of L929 cells in four different extracts was investigated by cell counting kit (CCK-8, Beyotime, Shanghai, China). In other words, the cell suspension $\left(10^{4}\right.$ cells $\left./ \mathrm{mL}\right)$ was separately cultured in $100 \mu \mathrm{L}$ of extract for 24,48 and $72 \mathrm{~h}$, respectively. The culture medium and CCK- 8 were put in a 96-well plate and maintained in $37^{\circ} \mathrm{C}$ incubator for $4 \mathrm{~h}$. After transferring the above mixed solution to a new well plate, the absorbance was read at $450 \mathrm{~nm}$ using a micro-plate reader (Bio-Rad 680, Hercules, CA, USA). According to the instruction manual, the cells cultured for 24, 48 and $72 \mathrm{~h}$ were qualitatively detected by a live/dead staining kit (Beyotime, Shanghai, China). Cell morphology and distribution were observed by fluorescence microscopy (Zeiss Axioskop 40, Jena, Germany).

\subsubsection{Cytotoxicity}

Toxicity of the samples to L929 cells was measured by detecting the content of lactate dehydrogenase (LDH, Biyuntian Biotechnology Co., Ltd., Shanghai, China) released into the culture medium. The cells $\left(10^{4}\right.$ cells $\left./ \mathrm{mL}\right)$ were seeded in ion extracts of four different samples immersed in different periods $(24,48$ and $72 \mathrm{~h}$ ), the supernatant was collected by centrifugation and the absorbance was read using a micro-plate reader to evaluate the LDH activity.

\subsection{Statistical Analysis}

All experimental data were expressed as mean \pm standard deviation (SD). Statistical analysis was carried out by student's test, and the difference was statistically significant $\left({ }^{*} p<0.05\right)$.

\section{Results}

\subsection{Materials Properties}

\subsubsection{Setting Time}

Setting time is an important indicator of bone cement, which not only provides sufficient operation time for clinical surgery, but also produces curing effect in a short time. The setting time of bone cement should be controlled between 3 and $15 \mathrm{~min}$, which is consistent with the optimal time for surgical operations [37]. Figure 1 shows the setting properties of pure $C_{3} S s$ and $\mathrm{Fe} / \mathrm{C}_{3} \mathrm{Ss}$ biomaterials. The results show that from Fe- 0 to Fe-10, the setting time of the material is reduced from $13.72 \pm 0.57$ to $9.72 \pm 0.31 \mathrm{~min}$. 


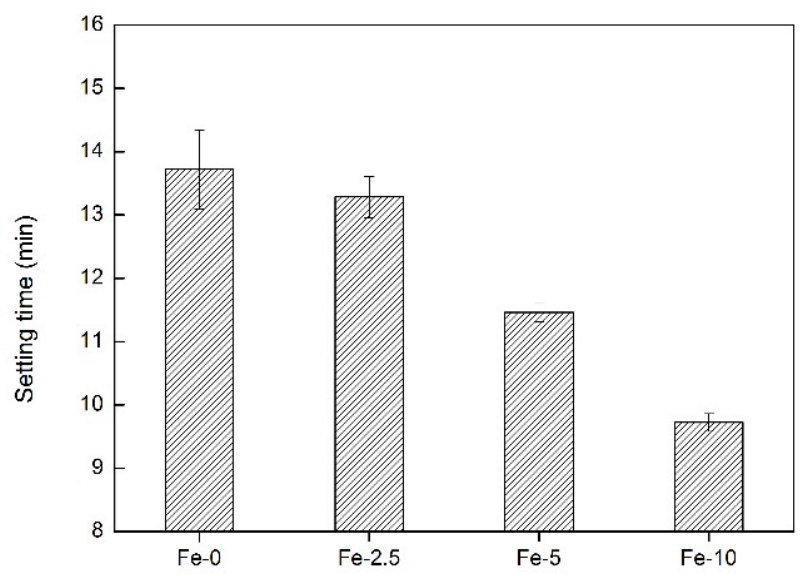

Figure 1. The setting time of Fe-0, Fe-2.5, Fe-5 and Fe-10 bone cement samples.

\subsubsection{Compressive Strength and Porosity}

For orthopedic surgery, it is necessary for bone repair materials to have a certain mechanical strength. Porosity of materials also has a certain influence on the growth of bone cells around the bone defect [38]. Therefore, the compressive strength and porosity of the $\mathrm{Fe} / \mathrm{C}_{3} \mathrm{~S}$ samples were both measured. As shown in Figure 2, with the increase of iron content, the numerical changes of the compressive strength and porosity of the samples present the opposite trend. For compressive strength, from $\mathrm{Fe}-0$ to Fe-10, the strength value decreases from $18.36 \pm 0.21$ to $12.59 \pm 0.56 \mathrm{MPa}$. With regard to porosity, the value increases from $35.20 \pm 0.48 \%$ to $47.53 \pm 0.27 \%$.

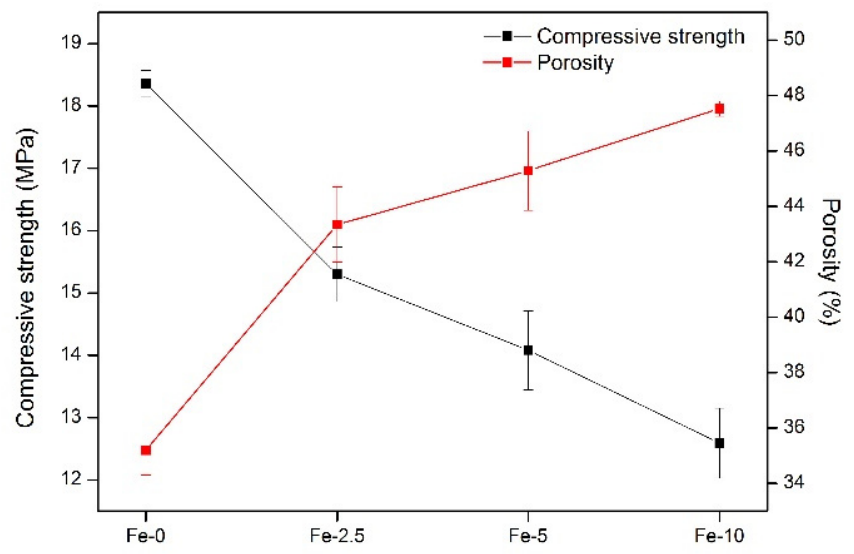

Figure 2. Compressive strength and porosity of Fe-0, Fe-2.5, Fe-5 and Fe-10 bone cement samples.

\subsection{In-Vitro Immersion Study}

\subsubsection{The $\mathrm{pH}$ Value}

The $\mathrm{pH}$ values of Fe-0, Fe-2.5, Fe-5 and Fe-10 samples are indicated in Figure 3a. The change of $\mathrm{pH}$ value is mainly due to the exchange of ions between the SBF solution and the samples. It can be seen that the $\mathrm{pH}$ value of the solution after immersion increases with the extension of the immersion time. In addition, after immersing for the same time, the $\mathrm{pH}$ value of $\mathrm{Fe}-0$ sample is higher than that of the three other samples. The $\mathrm{pH}$ values of $\mathrm{Fe} / \mathrm{C}_{3} \mathrm{Ss}$ samples are not significantly different, which can effectively reduce the higher $\mathrm{pH}$ value of pure $\mathrm{C}_{3} \mathrm{Ss}$ to a certain extent. 

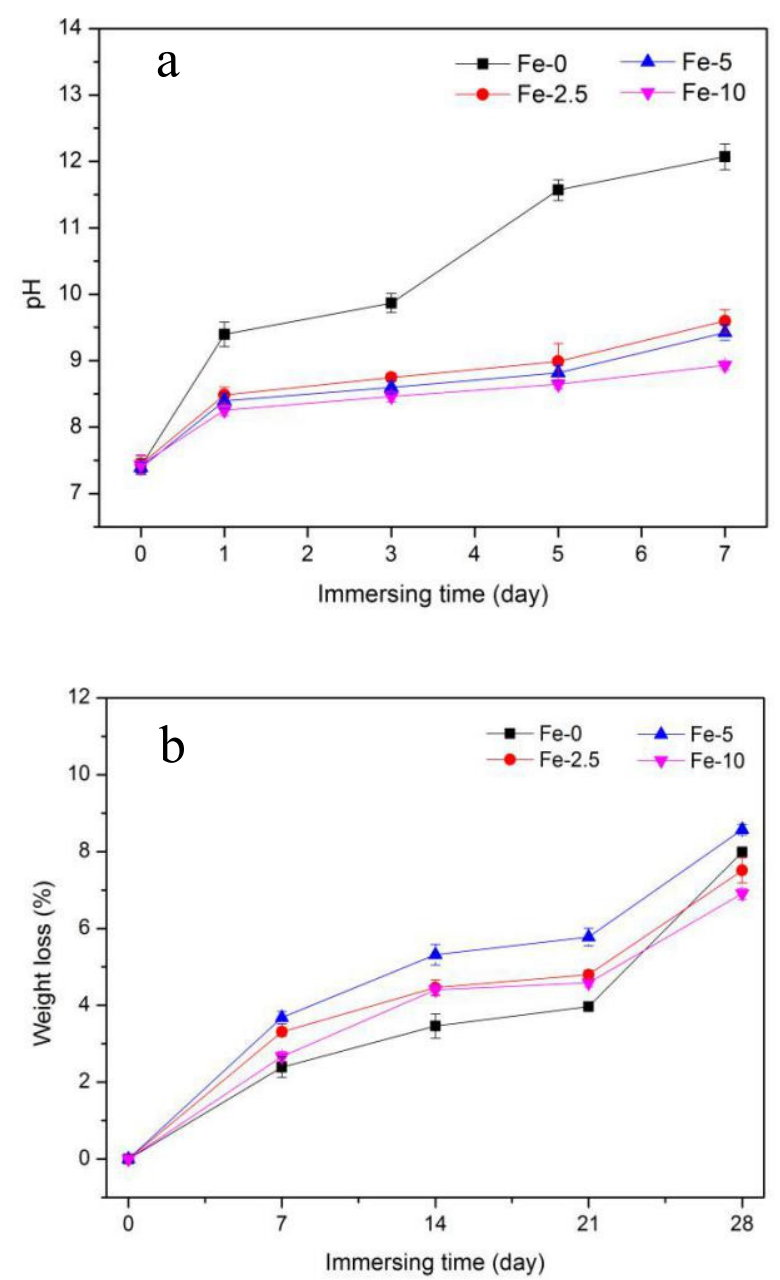

Figure 3. $\mathrm{pH}$ value (a); and weight loss (b) of Fe-0, Fe-2.5, Fe-5 and Fe-10 bone cement samples after immersing in SBF solution.

\subsubsection{Weight Loss}

Figure $3 \mathrm{~b}$ shows the weight loss of $\mathrm{C}_{3} \mathrm{Ss}$ and $\mathrm{Fe} / \mathrm{C}_{3} \mathrm{Ss}$ samples after immersing for different times in SBF solution $(0,7,14,21$ and 28 days). After immersing for 28 days, the weight loss rate of the materials was greater than other immersing times. For Fe-0, the weight loss rate rose from $2.39 \pm 0.26 \%$ to $7.99 \pm 0.11 \%$ during Days $7-28$. In the $\mathrm{Fe} / \mathrm{C}_{3}$ Ss samples, the value of Fe-5 increased from $3.68 \pm 0.16 \%$ to $8.58 \pm 0.14 \%$, which was higher than the weight loss of Fe-2.5 and Fe-10. Besides, the degradation rate of the materials after the 21 days of immersion became faster.

\subsubsection{Anti-Washout Property}

Figure 4 displays the anti-washout property of bone cement samples with different Fe contents after immersing in SBF solution for $60 \mathrm{~min}$. As shown in the enlarged images of Figure $4 \mathrm{~b}-\mathrm{f}$, no particle dispersion phenomenon was observed around the samples, which indicated that the samples have a good anti-washout property. 

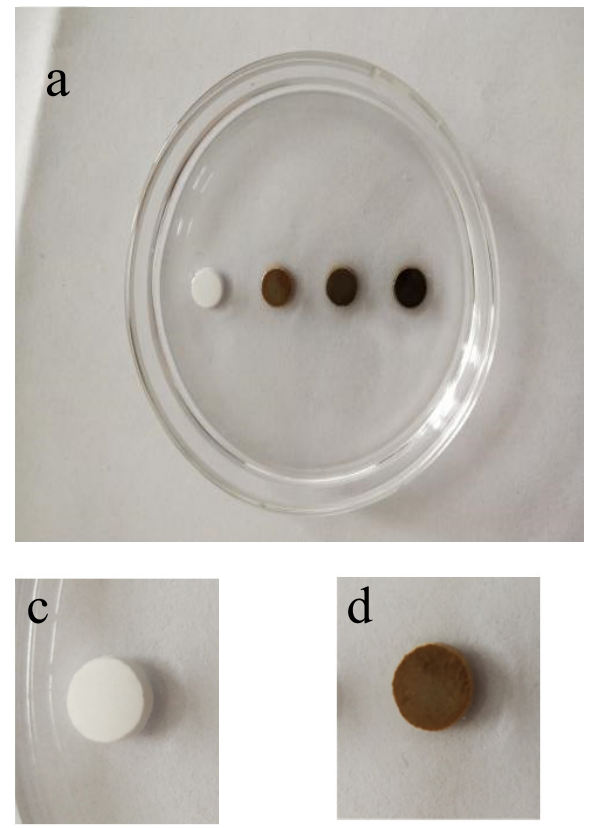
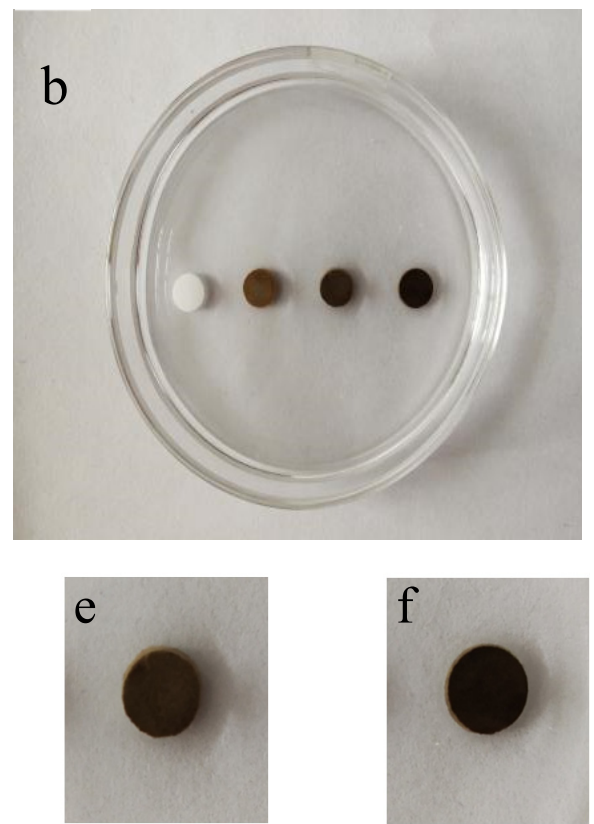

Figure 4. Anti-washout property of Fe-doped cement samples before (a) and after (b) immersing for $60 \mathrm{~min}$ in SBF solution (from left to right are Fe-0, Fe-2.5, Fe-5 and Fe-10); and (c-f) enlarged pictures of samples after immersing for $60 \mathrm{~min}$, respectively.

\subsection{In-Vitro Mineralization Characterization}

The XRD patterns of $\mathrm{C}_{3} \mathrm{~S}$ and $\mathrm{Fe} / \mathrm{C}_{3} \mathrm{~S}$ powders before and after immersing in SBF solution for seven days are shown in Figure 5. In the pattern before immersing, $\mathrm{C}_{3} \mathrm{~S}$ had obvious diffraction peaks at $2 \theta=32.1^{\circ}, 32.5^{\circ}, 34.3^{\circ}, 41.1^{\circ}, 51.7^{\circ}$ and $56.3^{\circ}$ (JCPDS No. 49-0442), respectively. The diffraction peaks of $\mathrm{C}_{2} \mathrm{~S}$ also appeared at $2 \theta=32.6^{\circ}, 41.3^{\circ}$ and $47.6^{\circ}$ (JCPDS No. 20-0237). In addition, a strong characteristic peak of hydrated calcium silicate (CSH) occurred at $29.4^{\circ}$ (JCPDS No. 43-1488), which was the result of hydration of $\mathrm{C}_{3} \mathrm{~S}$ or $\mathrm{C}_{2} \mathrm{~S}$. Moreover, the $\mathrm{Fe}_{2} \mathrm{O}_{3}$ phase exhibited a diffraction peak at $23.2^{\circ}$ (JCPDS No.39-0238). After immersing, the intensity of the $\mathrm{C}_{3} \mathrm{~S}$ diffraction peak decreased somewhat at $32.5^{\circ}$, which may be due to its continued hydration reaction in SBF solution. New diffraction peaks appeared at $2 \theta=32.9^{\circ}$ and $50.5^{\circ}$ (JCPDS No. 09-0432) due to the production of a new phase hydroxyapatite (HAp) after mineralization reaction.

Figure 6 shows the FT-IR spectra of $\mathrm{C}_{3} \mathrm{~S}$ and Fe-5 powders before and after immersing for seven days in SBF solution. The peaks at 1640 and $3400 \mathrm{~cm}^{-1}$ were typical vibrational peaks of $\mathrm{H}-\mathrm{O}-\mathrm{H}$ and $\mathrm{O}-\mathrm{H}$ bonds of crystalline water in hydrated calcium silicate, respectively $[39,40]$. The peak at about $1000 \mathrm{~cm}^{-1}$ corresponded to the anti-symmetric stretching vibration of the $\mathrm{Si}-\mathrm{O}$ in $\mathrm{C}_{3} \mathrm{~S}$ [40]. After immersing for seven days, a new absorption peak appeared at $1036 \mathrm{~cm}^{-1}$ in the FT-IR spectrum. This new peak corresponded to the $\mathrm{PO}_{4}{ }^{3-}$ asymmetric stretching vibration, which proved the existence of HAp and also confirmed the analysis results of XRD [41]. Besides, the peaks at positions of 561 and $1430 \mathrm{~cm}^{-1}$ were the stretching vibration peaks of $\mathrm{Fe}-\mathrm{O}$ bonds, indicating the presence of $\mathrm{Fe}_{2} \mathrm{O}_{3}$ phase in $\mathrm{Fe} / \mathrm{C}_{3} \mathrm{Ss}$ bone cement materials [42]. 

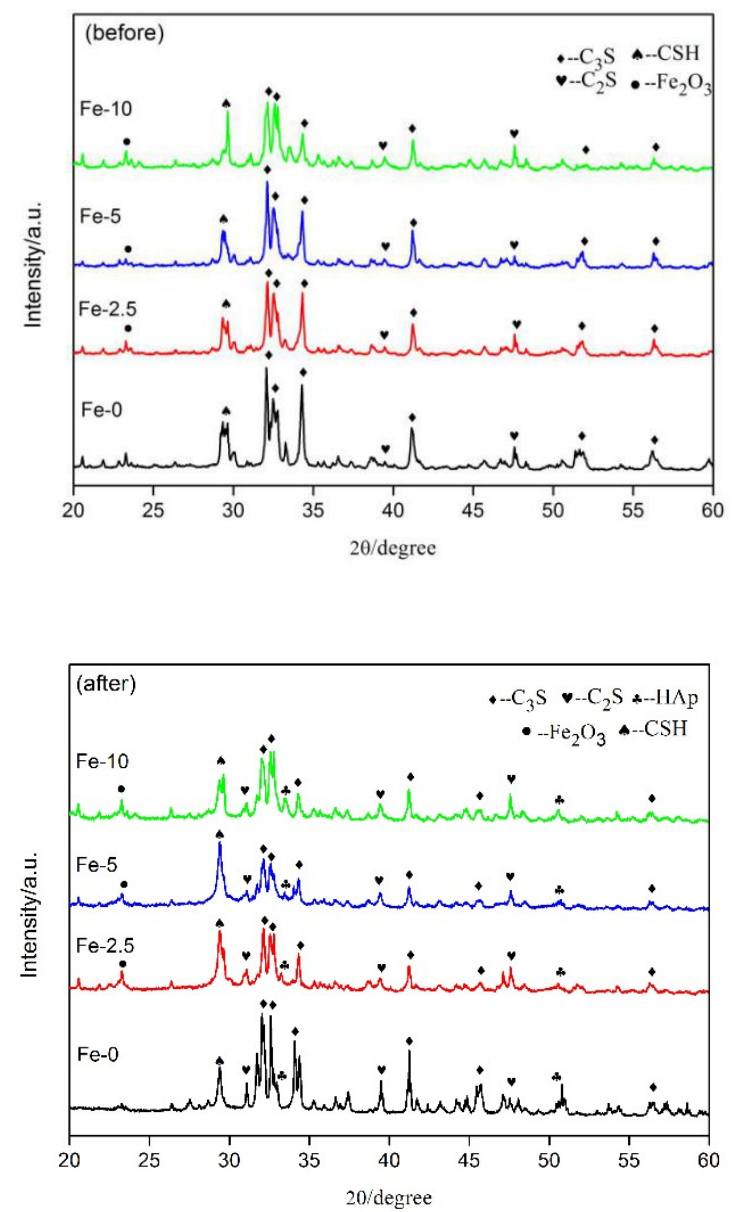

Figure 5. XRD patterns of Fe-0, Fe-2.5, Fe-5 and Fe-10 powders before and after immersing in SBF solution for seven days.

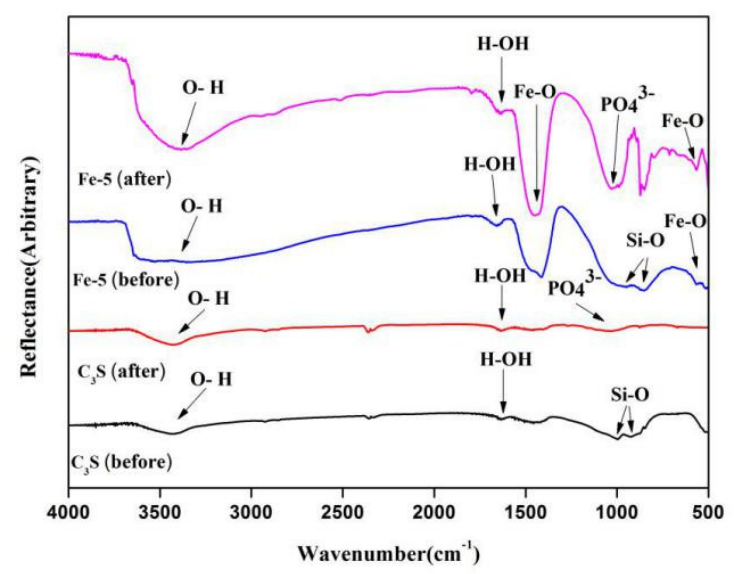

Figure 6. FT-IR spectra of $\mathrm{C}_{3} \mathrm{~S}$ and $\mathrm{Fe} / \mathrm{C}_{3} \mathrm{~S}$ powders before and after immersing in SBF solution for seven days.

In Figure 7, the SEM images of the surface of $\mathrm{Fe} / \mathrm{C}_{3} \mathrm{~S}$ s samples after immersing in SBF solution for seven days are shown. From the images, it can be seen that the samples were porous and rough. We found many small spherical particles appearing on all sample surfaces (Fe-5 is most obvious). Based on the results of XRD and FT-IR analysis, it could be determined that the spherical particle was HAp, which is similar to our previous study [39]. This shows that $\mathrm{Fe} / \mathrm{C}_{3} \mathrm{Ss}$ had certain biological activities in vitro. 

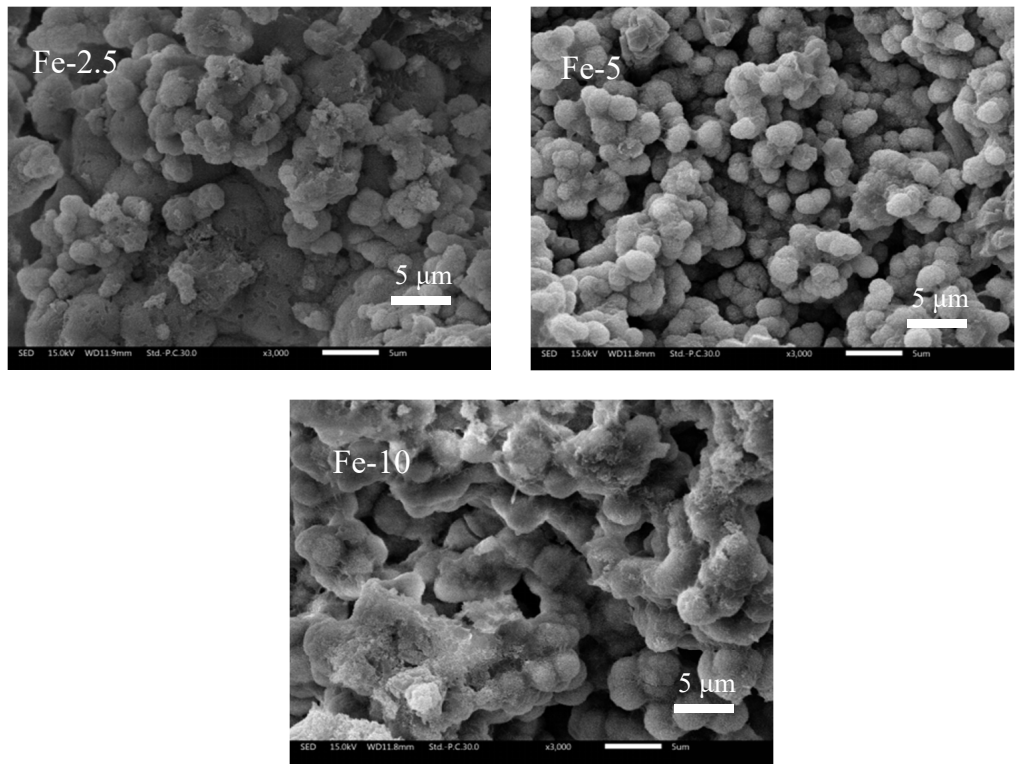

Figure 7. SEM images of $\mathrm{Fe} / \mathrm{C}_{3} \mathrm{Ss}$ samples after immersing in SBF solution for seven days.

\subsection{Cell Culture}

Figure 8 shows cell proliferation and LDH values after incubation of L929 cells in $\mathrm{C}_{3} \mathrm{Ss}$ and $\mathrm{Fe} / \mathrm{C}_{3} \mathrm{Ss}$ extract and control (DMEM) for 24,48 and $72 \mathrm{~h}$, respectively. Cellular fluorescence pictures after $72 \mathrm{~h}$ of incubation in Fe- 0 and Fe-5 extract are also exhibited. According to the cell proliferation in Figure $8 \mathrm{a}$, with the extension of culture time, the cell proliferation of $\mathrm{Fe} / \mathrm{C}_{3} \mathrm{~S}$ samples increased. The cell proliferation of $\mathrm{Fe}-5$ sample was the most obvious and higher than that of the control group and other experiment groups, indicating that $\mathrm{Fe}-5$ could promote cell proliferation.
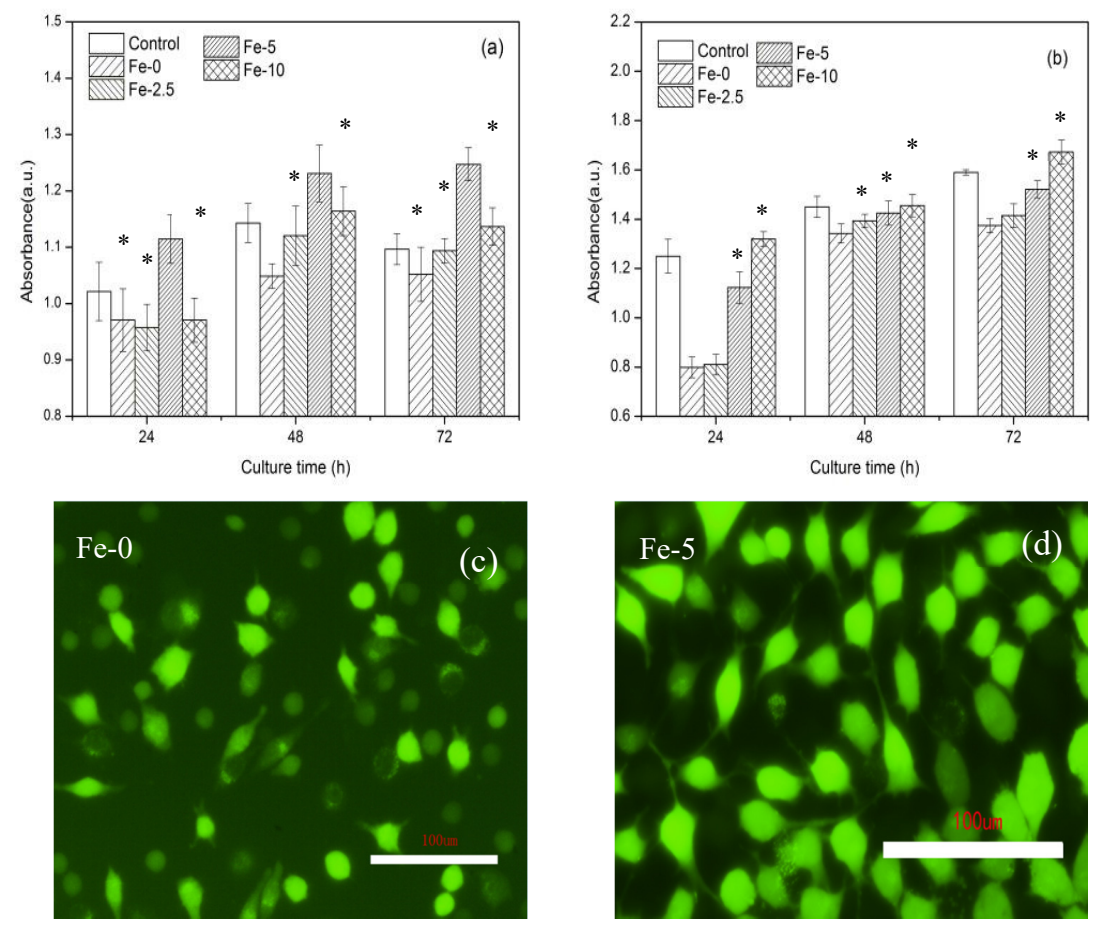

Figure 8. Cell proliferation (a) and LDH activity (b) after incubation of L929 cells in $\mathrm{Fe} / \mathrm{C}_{3} \mathrm{~S}$ extract and control (DMEM) for 24, 48 and $72 \mathrm{~h}$ and cellular fluorescence pictures (c,d) after $72 \mathrm{~h}$ of incubation in Fe- 0 and Fe-5 extracts. Error bars represent means \pm SD for $n=4\left({ }^{*} p<0.05\right)$. 
For the results in Figure $8 \mathrm{~b}$, the cytotoxicity also increased slightly. Compared with pure $\mathrm{C}_{3} \mathrm{Ss}$, $\mathrm{Fe} / \mathrm{C}_{3} \mathrm{Ss}$ samples showed a slightly higher cytotoxicity. However, the LDH activity of Fe-5 sample extract was close to that in the DMEM solution., indicating that Fe- 5 bone cement material possessed lower toxicity.

Figure $8 \mathrm{c}$, $\mathrm{d}$ shows that, when cells were cultured in the extract for $72 \mathrm{~h}$, many living cells (green spots) appeared in the extract of bone cement samples. Compared with pure $\mathrm{C}_{3} \mathrm{Ss}$, Fe-5 had the largest number of living cells, which is consistent with the results of cell proliferation.

\section{Discussion}

The setting time of the biomaterials required for different operations is different. The factors affecting the setting time of bone cement include temperature, particle size, solid-liquid ratio, powder composition, etc. [43]. On the one hand, iron ions are high-valent cations, which have a compressive effect on the diffused electric double layer of the hydration production CSH colloidal particles; thus, the coagulation of colloidal particles can be accelerated. On the other hand, mainly due to the high porosity of $\mathrm{Fe} / \mathrm{C}_{3} \mathrm{Ss}$ samples, when the sample powder was mixed with the curing liquid to form hydrated calcium silicate, it was filled with open pores that were originally filled with water, shortening the setting time [44].

In clinical application, it is necessary for bone cement material to offer adequate mechanical strength support at bone defect sites [37]. Compared with pure $\mathrm{C}_{3} \mathrm{Ss}, \mathrm{Fe} / \mathrm{C}_{3} \mathrm{Ss}$ showed lower strength. The main causes were that the valence and radius of calcium and iron ions $(0.99$ and $0.64 \AA$ ) are different and the stable structure of silicon-oxygen tetrahedron was distorted when $\mathrm{Ca}^{2+}$ was substituted by $\mathrm{Fe}^{3+}$ at its positions and other vacancies [11]. The increase of porosity was related to the certain decrease of compressive strength. After Fe ions replaced more Ca ions, the formation of CSH gel was relatively small. It was difficult to fully fill the gaps between powder particles with Fe content, resulting in increased porosity. At the same time, the addition of nano-oxide could also increase the porosity, which can be observed in SEM images [45].

Owing to $\mathrm{C}_{3} \mathrm{~S}$ as the primary component, the hydration reaction occurred in the solution to produce calcium hydroxide $\left(\mathrm{Ca}(\mathrm{OH})_{2}\right)$, a highly alkaline byproduct, which led to the $\mathrm{pH}$ value of solution increasing rapidly after immersing for one day. After that, the $\mathrm{pH}$ value increased slowly because the formation of hydroxyapatite (HAp) on the samples' surface partially consumed $\mathrm{OH}^{-}$. After immersing for five days, with $\mathrm{PO}_{4}{ }^{3-}$ depleted, $\mathrm{OH}^{-}$in the solution was no longer consumed. Some unhydrated $\mathrm{C}_{3} \mathrm{Ss}$ continued to be hydrated in SBF solution, which led to the increase of $\mathrm{pH}$ value. However, at the same time point, the $\mathrm{pH}$ of $\mathrm{C}_{3} \mathrm{Ss}$ was higher than that of $\mathrm{Fe} / \mathrm{C}_{3} \mathrm{Ss}$, which was due to the partial substitution of $\mathrm{Ca}^{2+}$ by $\mathrm{Fe}^{3+}$ in the preparation of the powders, resulting in a relatively small amount of $\mathrm{Ca}(\mathrm{OH})_{2}$.

Biodegradability is one of the significant factors to evaluate the performance of bone cement, and the test process is mainly carried out by means of ion release [1]. Compared with Fe- 0 and Fe-2.5, the higher degradation rate of Fe- 5 was attributed to its larger porosity and lower strength. It was much easier with larger surface area to degrade in SBF solution. The main reason the weight loss of Fe-10 was lower than that of Fe- 5 was that its higher porosity led to its lower density at the same volume and its degradation amount was limited. As the degradation continued, the porosity increased. The increased contact surface between the solution and the material made the material easier to degrade, which explained the acceleration of degradation rate in the later stage of degradation.

Anti-washout performance is the basic clinical requirement for bone cement. The experimental results show that $\mathrm{C}_{3} \mathrm{Ss}$ and $\mathrm{Fe} / \mathrm{C}_{3} \mathrm{Ss}$ had a good anti-washout property, which could be explained in two ways. Firstly, the material had large compressive strength and its cohesive force was large. Secondly, it might be related to the formation of calcium silicate gel with high bulk density in SBF solution after immersing. 
The SEM images confirmed that the surface of the samples immersed in SBF solution formed a large number of HAp spherical particles. The formation of particles could be explained by the release of $\mathrm{Ca}^{2+}$ into the solution and exchange with $\mathrm{H}^{+}$in SBF to form silanol groups ( $\mathrm{Si}-\mathrm{OH}$ ). This provided a nucleation site for the formation of HAp. The dense spherical particles on the surface of Fe-5 might be related to the difference in composition and porosity between samples.

In cell experiments, the cell proliferation and fluorescence images well proved that Fe-5 sample had excellent proliferation effect. There are several reasons to explain it. Firstly, the alkalinity of the material has a great influence on proliferation. The closer is the $\mathrm{pH}$ value of the material to human body fluid, the better is the cell proliferation. Pure $\mathrm{C}_{3} \mathrm{~S}$ has a higher alkalinity, which tends to inhibit cell proliferation and growth. Secondly, the porosity of the sample also has some effects on cell proliferation. In the preparation of extract, Fe-5 had larger porosity than pure $\mathrm{C}_{3} \mathrm{~S}$, which was conducive to the release of $\mathrm{Ca}$ and $\mathrm{Si}$ ions, and the released ions were beneficial to the osteogenic differentiation of cells, thus promoting cell proliferation. Despite the lower $\mathrm{pH}$ value and high porosity of Fe-10, the release of Ca content was limited, which was not conducive to cell proliferation. For Fe-5 with low cytotoxicity, the $\mathrm{pH}$ value might be close to that of body fluid, thus it was less harmful to cells. Finally, the introduction of iron ions also had a positive effect on cell culture and bone regeneration [46]. The release level of $\mathrm{Si}, \mathrm{Ca}$ and Fe ions was a limitation in the current study, which will be considered in the follow-up study. In addition, an animal model study by Matsumoto et al. showed that hydrated calcium silicate cement has a positive interaction with bone tissue [47]. Shi et al. [24] and Ullah et al. [48] also confirmed the positive effects of iron-containing biomaterials on promoting angiogenesis and osteogenic differentiation. Therefore, animal model studies of iron-containing tricalcium silicate bone cement will also be carried out in future studies. Based on the above results, in vitro cell experiments showed that Fe-5 bone cement had good cell compatibility.

\section{Conclusions}

In this study, the iron-containing tricalcium silicate bone cement material was successfully prepared by sol-gel method. $\mathrm{Fe} / \mathrm{C}_{3} \mathrm{Ss}$ have some properties that can meet the requirements of clinical surgery, such as better self-curing behavior, excellent biomechanical properties and suitable biodegradation rate. Compared with $\mathrm{C}_{3} \mathrm{Ss}$, Fe-5 with lower $\mathrm{pH}$ value and larger porosity was more suitable for cell growth. At the same time, in vitro mineralization experiments showed that the material had larger degradation rate and good biological activity. In addition, in vitro cell experiments demonstrated that Fe-5 had good cell proliferation and low cytotoxicity, indicating that it had good cell compatibility. Therefore, Fe-doped tricalcium silicate-based bone cement biomaterial is a promising material in the treatment of bone defects.

Author Contributions: Conceptualization, J.L. and Y.Z. (Yin Zhang); software, S.S., S.L., S.X. and D.X.; formal analysis, J.L.; investigation, J.L., Y.Z. (Yin Zhang), S.S., S.L., S.X. and D.X.; resources, Y.Z. (Yin Zhang) and Y.Z. (Yanan Zhang); data curation, J.L.; writing-original draft preparation, J.L.; writing-review and editing, Y.Z. (Yin Zhang) and Y.Z. (Yanan Zhang); funding acquisition, Y.Z. (Yanan Zhang). All authors have read and agreed to the published version of the manuscript.

Funding: This research was funded by the Natural Science Foundation of Jiangsu Province, grant number BK20180495 and BK20180698. This work was financially supported by the Priority Academic Program Development of Jiangsu Higher Education Institutions, Jiangsu Collaborative Innovation Center for Advanced Inorganic Function Composites and Postgraduate Research \& Practice Innovation Program of Jiangsu Province. The authors gratefully acknowledge the financial support of the Natural Science Foundation of Jiangsu Province (BK20180495 and BK20180698).

Conflicts of Interest: The authors declare that no conflict of interest is involved in this paper and the authors are responsible for the content and writing. 


\section{References}

1. Gandolf, M.G.; Zamparini, F.; Esposti, M.D.; Chiellini, F.; Fava, F.; Fabbri, P.; Taddei, P.; Prati, C. Highly porous polycaprolactone scaffolds doped with calcium silicate and dicalcium phosphate dihydrate designed for bone regeneration. Mater. Sci. Eng. C 2019, 102, 341-361. [CrossRef] [PubMed]

2. Bai, X.; Gao, M.Z.; Syed, S.; Zhuang, J.; Xu, X.Y.; Zhang, X.Q. Bioactive hydrogels for bone regeneration. Bioact. Mater. 2018, 3, 401-417. [CrossRef] [PubMed]

3. De Grado, G.F.; Keller, L.; Idoux-Gillet, Y.; Wagner, Q.; Musset, A.M.; Benkirane-Jessel, N.; Bornert, F.; Offner, D. Bone substitutes: A review of their characteristics, clinical use, and perspectives for large bone defects management. J. Tissue Eng. 2018, 9, 1-18.

4. Winkler, T.; Sass, F.A.; Duda, G.N.; Schmidt-Bleek, K. A review of biomaterials in bone defect healing, remaining shortcomings and future opportunities for bone tissue engineering. Bone Joint Res. 2018, 7, $232-243$. [CrossRef]

5. Tian, L.; Tang, N.; Ngai, T.; Wu, C.; Ruan, Y.C.; Huang, L.; Qin, L. Hybrid fracture fixation systems developed for orthopaedic applications: A general review. J. Orthop. Transl. 2019, 16, 1-13. [CrossRef] [PubMed]

6. Luo, C.Q.; Fang, Y.; Tu, C.Q.; Yang, T.F. Current treatment situation and progress on bone defect of collapsed tibial plateau fractures. China. J. Orthop. Trauma. 2016, 29, 187-191.

7. Howard, J.; Gardner, L.; Saifee, Z.; Geleil, A.; Nelson, I.; Colombo, J.S.; Naleway, S.E.; Carlson, K. Synthesis and characterization of novel calcium phosphate glass-derived cements for vital pulp therapy. J. Mater. Sci. Mater. Med. 2020, 31, 12. [CrossRef]

8. Abdalla, M.M.; Lung, C.Y.K.; Neelakantan, P.; Matinlinna, J.P. A novel, doped calcium silicate bioceramic synthesized by sol-gel method: Investigation of setting time and biological properties. J. Biomed. Mater. Res. $B$ 2020, 108, 56-66. [CrossRef]

9. Das, E.C.; Kumary, T.V.; Anil Kumar, P.R.; Komath, M. Calcium sulfate-based bioactive cement for periodontal regeneration: An in vitro study Indian. J. Dent. Res. 2019, 30, 558-567.

10. Ho, C.C.; Wei, C.K.; Lin, S.Y.; Ding, S.J. Calcium silicate cements prepared by hydrothermal synthesis for bone repair. Ceram. Int. 2016, 42, 9183-9189. [CrossRef]

11. Shi, S.H.; Ye, X.L.; Zhang, J.; Ye, J.D. Enhanced osteogenesis of injectable calcium phosphate bone cement mediated by loading chondroitin sulfate. ACS Biomater. Sci. Eng. 2019, 5, 262-271. [CrossRef]

12. Li, L.; Wang, R.C.; Li, B.C.; Lian, W.; Pan, H.B.; Cui, X.; Tang, J.L.; Li, B. Lithium doped calcium phosphate cement maintains physical mechanical properties and promotes osteoblast proliferation and differentiation. J. Biomed. Mater. Res. Part B 2017, 105, 944-952. [CrossRef] [PubMed]

13. Vahabzadeh, S.; Bose, S. Effects of iron on physical and mechanical properties, and osteoblast cell interaction in $\beta$-tricalcium phosphate. Ann. Biomed. Eng. 2017, 45, 819-828. [CrossRef]

14. Zhang, L.; Huang, X.Y.; Han, Y. Formation mechanism and cytocompatibility of nano-shaped calcium silicate hydrate/calcium titanium silicate/ $/ \mathrm{TiO}_{2}$ composite coatings on titanium. J. Mater. Chem. B 2016, 4, 6734-6745. [CrossRef]

15. Huang, T.H.; Kao, C.T.; Shen, Y.F.; Lin, Y.T.; Liu, Y.T.; Yen, S.Y.; Ho, C.C. Substitutions of strontium in bioactive calcium silicate bone cements stimulate osteogenic differentiation in human mesenchymal stem cells. J. Mater. Sci. 2019, 30, 68. [CrossRef] [PubMed]

16. Chen, Y.W.; Hsu, T.T.; Wang, K.; Shie, M.Y. Preparation of the fast setting and degrading Ca-Si-Mg cement with both odontogenesis and angiogenesis differentiation of human periodontal ligament cells. Mater. Sci. Eng. C 2016, 60, 374-383. [CrossRef]

17. Cao, W.J.; Peng, Y.Y.; Zhang, Y.; Qiu, F.; Li, M.M.; Tang, J.; Wu, Z.N. Novel bone wax based on tricalcium silicate cement and BGs mixtures. Biomed. Mater. 2018, 13, 065001. [CrossRef]

18. Carlisle, E.M. Silicon: A requirement in bone formation independent of vitamin D1. Calcif. Tissue 1981, 33, 27-34. [CrossRef]

19. Liu, W.C.; Wang, H.Y.; Chen, L.C.; Huang, S.W.; Wu, C.T.; Chung, R.J. Hydroxyapatite/tricalcium silicate composites cement derived from novel two-step sol-gel process with good biocompatibility and applications as bone cement and potential coating materials. Ceram. Int. 2019, 45, 5668-5679. [CrossRef]

20. Liu, W.C.; Hu, C.C.; Tseng, Y.Y.; Sakthivel, R.; Fan, K.S.; Wang, A.N.; Wang, Y.M.; Chung, R.J. Study on strontium doped tricalcium silicate synthesized through sol-gel process. Mater. Sci. Eng. C 2020, 108, 110431. [CrossRef] 
21. An, S.F.; Gao, Y.; Ling, J.Q.; Wei, X.Y.; Xiao, Y. Calcium ions promote osteogenic differentiation and mineralization of human dental pulp cells: Implications for pulp capping materials. J. Mater. Sci. Mater. Med. 2012, 23, 789-795. [CrossRef] [PubMed]

22. Forni, M.; Bernardini, C.; Zamparini, F.; Zannoni, A.; Salaroli, R.; Ventrella, D.; Parchi, G.; Esposti, M.D.; Polimeni, A.; Fabbri, P.; et al. Vascular wall-mesenchymal stem cells differentiation on 3D biodegradable highly porous CaSi-DCPD doped poly (alpha-hydroxy) acids scaffolds for bone regeneration. Nanomaterials 2020, 10, 243. [CrossRef] [PubMed]

23. Li, G.D.; Zhang, N.; Zhao, S.T.; Zhang, K.L.; Li, X.Y.; Jing, A.H.; Liu, X.P.; Zhang, T. Fe-doped brushite bone cements with antibacterial property. Mater. Lett. 2018, 215, 27-30. [CrossRef]

24. Shi, H.S.; Yang, S.Y.; Zeng, S.H.; Liu, X.; Zhang, J.; Zhang, J.; Wu, T.T.; Ye, X.L.; Yu, T.; Zhou, C.R.; et al. Enhanced angiogenesis of biodegradable iron-doped octacalcium phosphate/poly (lactic-co-glycolic acid) scaffold for potential cancerous bone regeneration. Appl. Mater. Today 2019, 15, 100-114. [CrossRef]

25. Zhang, J.; Shi, H.S.; Liu, J.Q.; Yu, T.; Shen, Z.H.; Ye, J.D. Good hydration and cell-biological performances of superparamagnetic calcium phosphate cement with concentration-dependent osteogenesis and angiogenesis induced by ferric iron. J. Mater. Chem. B 2015, 3, 8749-8912. [CrossRef]

26. Xia, Y.; Chen, H.M.; Zhang, F.M.; Wang, L.; Chen, B.; Reynolds, M.A.; Ma, J.Q.; Schneider, A.; Gu, N.; $\mathrm{Xu}, \mathrm{H} . \mathrm{H} . K$. Injectable calcium phosphate scaffold with iron oxide nanoparticles to enhance osteogenesis via dental pulp stem cells. Artif. Cell Nanomed. Biotechnol. 2018, 46, S423-S433. [CrossRef]

27. Cao, W.J.; Zong, S.Y.; Zhang, Y.; Qiu, F.; Tang, J.; Wu, Z.N.; Luan, J.P. Preparation of a novel bone wax with modified tricalcium silicate cement and BGs. Mater. Sci. Eng. C 2019, 99, 979-985. [CrossRef]

28. Farzin, A.; Fathi, M.; Emadi, R. Multifunctional magnetic nanostructured hardystonite scaffold for hyperthermia, drug delivery and tissue engineering applications. Mater. Sci. Eng. C 2017, 70, 21-31. [CrossRef]

29. Babu, M.M.; Rao, P.V.; Veeraiah, N.; Prasad, P.S. Effect of $\mathrm{Al}^{3+}$ ions substitution in novel zinc phosphate glasses on formation of HAp layer for bone graft applications. Colloids Surf. B 2020, 185, 110591. [CrossRef]

30. Lewandowska, K.; Furtos, G. Study of apatite layer formation on SBF-treated chitosan composite thin films. Polym. Test. 2018, 71, 173-181. [CrossRef]

31. Tang, J.; Cao, W.J.; Zhang, Y.; Luan, J.P.; Jiang, F.; Zhou, X.; Li, M.M. Properties of vaterite-containing tricalcium silicate composited graphene oxide for biomaterials. Biomed. Mater. 2019, 14, 045004. [CrossRef] [PubMed]

32. Ma, C.M.; Ma, Z.Y.; Yang, F.; Wang, J.; Liu, C.S. Poly (propylene fumarate)/ $\beta$-calcium phosphate composites for enhanced bone repair. Biomed. Mater. 2019, 14, 045002. [CrossRef] [PubMed]

33. Feng, S.P.; Li, J.Y.; Jiang, X.S.; Li, X.F.; Pan, Y.K.; Zhao, L.M.; Boccaccini, A.R.; Zheng, K.; Yang, L.L.; Wei, J. Influences of mesoporous magnesium silicate on the hydrophilicity, degradability, mineralization and primary cell response to a wheat protein based biocomposite. J. Mater. Chem. B 2016, 4, 6428-6436. [CrossRef] [PubMed]

34. Shu, Y.; Qiu, F.; Zhang, Y.; Cao, W.J.; Wu, Z.N.; Nian, S.J.; Zhou, N.Y. Novel vaterite-containing tricalcium silicate bone cement by surface functionalization using 3-aminopropyltriethoxysilane: Setting behavior, in vitro bioactivity and cytocompatibility. Biomed. Mater. 2017, 12, 065007. [CrossRef] [PubMed]

35. Sengupta, S.; Khatua, C.; Balla, V.K. In vitro carcinoma treatment using magnetic nanocarriers under ultrasound and magnetic fields. ACS Omega 2018, 3, 5459-5469. [CrossRef] [PubMed]

36. Ji, M.Z.; Ding, Z.W.; Chen, H.; Peng, H.T.; Yan, Y.G. Design of novel organic-inorganic composite bone cements with high compressive strength, in vitro bioactivity and cytocompatibility. J. Biomed. Mater. Res. Part B 2019, 7, 2365-2377. [CrossRef]

37. Bercier, A.; Gonçalves, S.; Lignon, O.; Fitremann, J. Calcium phosphate bone cements including sugar surfactants: Part one-porosity, setting times and compressive strength. Materials 2010, 3, 4695-4709. [CrossRef]

38. Mouzakis, D.; Zaoutsos, S.P.; Bouropoulos, N.; Rokidi, S.; Papanicolaou, G. Influence of artificially-induced porosity on the compressive strength of calcium phosphate bone cements. J. Biomater. Appl. 2016, 31, 112-120. [CrossRef]

39. Lee, B.S.; Lin, H.P.; Chan, J.C.C.; Wang, W.C.; Hung, P.H.; Tsai, Y.H.; Lee, Y.L. A novel sol-gel-derived calcium silicate cement with short setting time for application in endodontic repair of perforations. Int. J. Nanomed. 2018, 13, 261-271. [CrossRef]

40. Lee, Y.L.; Wang, W.H.; Lin, F.H.; Lin, C.P. Hydration behaviors of calcium silicate-based biomaterials. J. Formos. Med. Assoc. 2017, 116, 424-431. [CrossRef] 
41. Zhang, Q.C.; Le, Z.L.; Peng, M.X.; Zhong, M.L.; Wan, Y.Z.; Luo, H.L. Enhancement of mechanical and biological properties of calcium phosphate bone cement by incorporating bacterial cellulose. Mater. Technol. 2019, 34, 800-806. [CrossRef]

42. Zhao, Y.; Fan, T.T.; Chen, J.D.; Su, J.C.; Pan, P.P.; Zou, L.; Zhang, Q.Q. Magnetic bioinspired micro/nanostructured composite scaffold for bone regeneration. Colloids Surf. B 2019, 174, 70-79. [CrossRef] [PubMed]

43. Quintana, R.M.; Jardine, A.P.; Grechi, T.R.; Soares, R.G.; Ardenghi, D.M.; Scarparo, R.K.; Grecca, F.S.; Kopperl, P.M.P. Bone tissue reaction, setting time, solubility, and $\mathrm{pH}$ of root repair materials. Clin. Oral. Investig. 2018, 23, 1359-1366. [CrossRef] [PubMed]

44. Heikal, M.; Ibrahim, N.S. Hydration, microstructure and phase composition of composite cements containing nano-clay. Constr. Build. Mater. 2016, 112, 19-27. [CrossRef]

45. Sanjuán, M.A.; Argiz, C.; Gálvez, J.C.; Reyes, E. Combined effect of nano-SiO $\mathrm{S}_{2}$ and nano- $\mathrm{Fe}_{2} \mathrm{O}_{3}$ on compressive strength, flexural strength, porosity and electrical resistivity in cement mortars. Mater. Construc. 2018, 68, 10716. [CrossRef]

46. Xia, Y.; Chen, H.M.; Zhao, Y.T.; Zhang, F.M.; Li, X.D.; Wang, L.; Weir, M.D.; Ma, J.Q.; Reynolds, M.A.; $\mathrm{Gu}, \mathrm{N}$.; et al. Novel magnetic calcium phosphate-stem cell construct with magnetic field enhances osteogenic differentiation and bone tissue engineering. Mater. Sci. Eng. C Mater. 2019, 98, 30-41. [CrossRef] [PubMed]

47. Matsumoto, S.; Hayashi, M.; Suzuki, Y.; Suzuki, N.; Maeno, M.; Ogiso, B. Calcium ions released from mineral trioxide aggregate convert the differentiation pathway of $\mathrm{C} 2 \mathrm{C} 12$ cells into osteoblast lineage. J. Endod. 2013, 39, 68-75. [CrossRef]

48. Ullah, I.; Gloria, A.; Zhang, W.C.; Ullah, M.W.; Wu, B.; Li, W.C.; Domingos, M.; Zhang, X.L. Synthesis and characterization of sintered $\mathrm{Sr} / \mathrm{Fe}$-modified hydroxyapatite bioceramics for bone tissue engineering applications. ACS Biomater. Sci. Eng. 2020, 6, 375-388. [CrossRef]

(C) 2020 by the authors. Licensee MDPI, Basel, Switzerland. This article is an open access article distributed under the terms and conditions of the Creative Commons Attribution (CC BY) license (http://creativecommons.org/licenses/by/4.0/). 